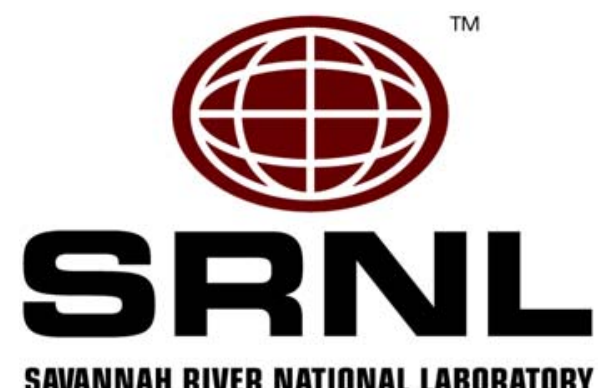

\title{
MATERIALS SCIENCE AND TECHNOLOGY
}

\section{Tritium Effects on Weldment Fracture Toughness}

\author{
M. J. Morgan, M. H. Tosten, and S. L. West
}

Publication Date: July 17, 2006

\section{Savannah River National Laboratory \\ Washington Savannah River Company \\ Savannah River Site \\ Aiken, South Carolina}

This document was prepared in connection with work done under Contract No. DE-AC09-96R18500 with the U. S. Department of Energy. By acceptance of this document, the publisher and/or recipient acknowledges the U. S. Government's right to retain a nonexclusive, royalty-free license in and to any copyright covering this document, along with the right to reproduce and authorize others to reproduce all or part of the copy righted material.

The WSRC Team: Washington Savannah River Company LLC • Bechtel Savannah River, Inc. • BNG America Savannah River Corporation • BWXT Savannah River Company • CH2 Savannah River Company 


\section{DISCLAIMER}

This report was prepared as an account of work sponsored by an agency of the United States Government. Neither the United States Government nor any agency thereof, nor any of their employees, nor any of their contractors, subcontractors or their employees, makes any warranty, express or implied, or assumes any legal liability or responsibility for the accuracy, completeness, or any third party's use or the results of such use of any information, apparatus, product, or process disclosed, or represents that its use would not infringe privately owned rights. Reference herein to any specific commercial product, process, or service by trade name, trademark, manufacturer, or otherwise, does not necessarily constitute or imply its endorsement, recommendation, or favoring by the United States Government or any agency thereof or its contractors or subcontractors. The views and opinions of authors expressed herein do not necessarily state or reflect those of the United States Government or any agency thereof. 


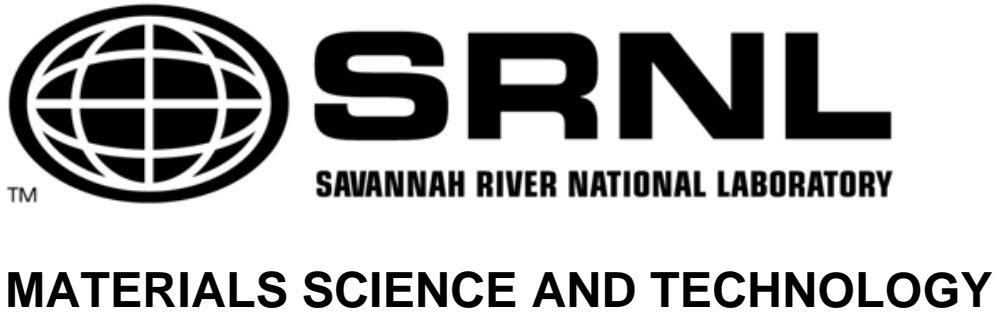

July 17, 2006
Keywords: Stainless Steel 304L Hydrogen Helium J Integral

Retention: Permanent

\section{Tritium Effects on Weldment Fracture Toughness}

M. J. Morgan, M. H. Tosten, and S. L. West

Materials Science and Technology

Savannah River National Laboratory, Aiken, South Carolina 29808

\section{Washington Savannah River Company}

Prepared for the U. S. Department of Energy under Contract DE-AC09-96SR18500 


\section{APPROVALS}

Г⿸丆口⺕亅

M. J. Morgan, Autho

MATERIALS COMPATIBILITY AND WELDING TECHNOLOGY GROUP

MATERIALS SCIENCE AND TECHNOLOGY

M. Ȟ. Tosten, Author

MATERIALS COMPATIBILITY AND WELDING TECHNOLOGY GROUP

MATERIALS SCIENCE AND TECHNOLOGY
DATE: $7 / 18 / 2006$

DATE: $7 / 17 / 2006$

DATE: $7 / 18 / 2006$

S. L. West, Author

WEAPONS TECHNOLOGY GROUP

HYDROGEN TECHNOLOGY

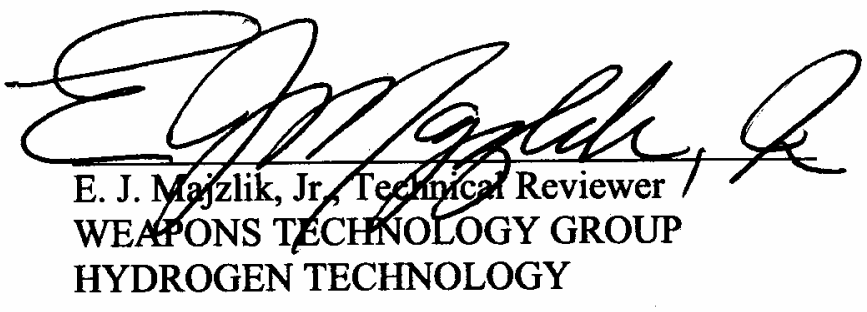

DATE: $7 / 2 / 06$

$\bar{M}$. E. Dupont, Manager

DATE: $7 / 18 / 06$

MATERIALS COMPATIBILITY AND WELDING TECHNOLOGY GROUP

MATERIALS SCIENCE AND TECHNOLOGY

N. C. Iyer, Director

DATE: $7 / 18 / 06$ MATERIALS SCIENCE AND TECHNOLOGY 


\section{Tritium Effects on Weldment Fracture Toughness}

\section{CONTENTS}

\section{Page}

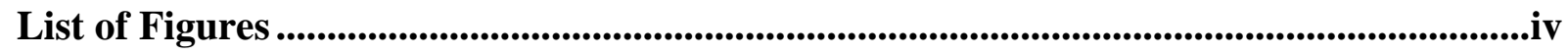

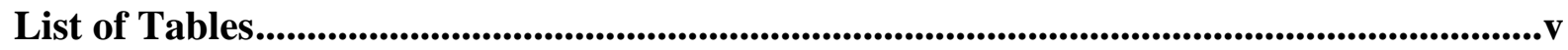

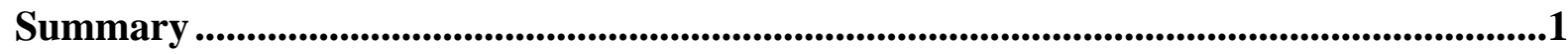

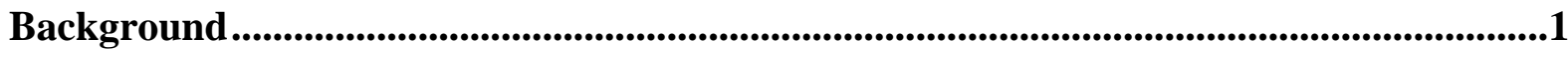

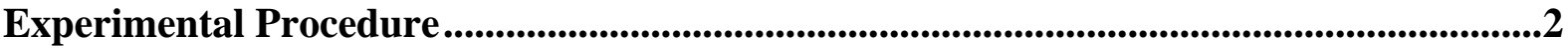

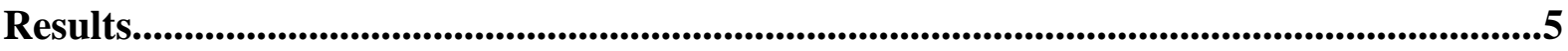

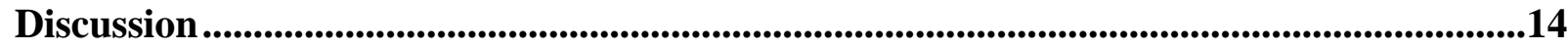

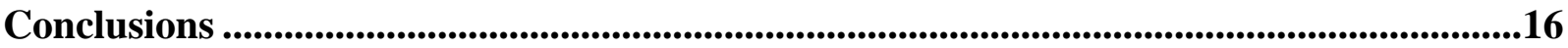

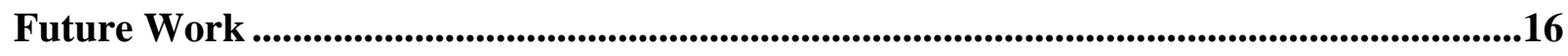

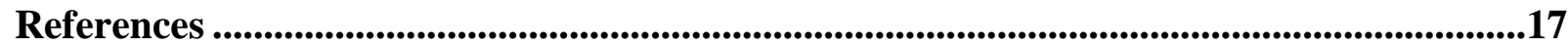


Figure 1. Type 304L Forging with Cut Grooves and Weldments Made Using 2 Types 308L, 309L MOD, and 312 MOD Filler Materials.

Figure 2. Shape and Dimensions of Fracture Toughness Sample. 2

Figure 3. Typical Microstructure of Type 304L Base Metal Used in this Study. 5

Figure 4. Microstructure of Welds that Consisted of Discontinuous Skeletal 5 Ferrite in an Austenite Matrix.

$\begin{array}{ll}\text { Figure 5. TEM Images From the Forged Specimen Material. } & 7\end{array}$

Figure 6. TEM Images of (a) an Austenite/Ferrite Interface and (b) the Helium 8 Bubble Distribution in the Austenite Grain in (a).

Figure 7. TEM Images from Forged Material. $\quad 9$

Figure 8. Typical Load-Displacement and Potential-Drop-Crack-Length- 10 Measurement Records Acquired During Fracture Toughness Test.

Figure 9. J-Integral vs. Change in Crack Length, J-da, Behavior for Unexposed 12 Base Metals and Welds.

Figure 10. J-Integral vs. Change in Crack Length, J-da, Behavior for Unexposed 12 and Tritium-Exposed Type 304L Base Metal.

Figure 11. J-da Behavior for Unexposed and Tritium-Exposed Weldments. 13

Figure 12. Reduction in Fracture Toughness with Increasing Helium Content. 13

Figure 13. Fracture Appearance of Unexposed Steels: (a) Type 304L Base Metal; 14 and (b) Type 304L/308L Weld Metal.

Figure 14. Fracture Appearance of Tritium-Exposed Samples: (a) Type 304L Base Metal; and (b) Type 304L/308L Weld Metal. 
Table I. Composition of Stainless Steel Forgings, Plates and Weld Filler Wires.

Table II. Tritium and Helium Contents for Tritium-Exposed Base Metal and Weldments

Table III. Mechanical Properties and Fracture Toughness Values for Base Metals and Weldments 
WSRC-STI-2006-00056 


\section{Tritium Effects on Weldment Fracture Toughness}

\section{Summary}

The effects of tritium on the fracture toughness properties of Type 304L stainless steel and its weldments were measured. Fracture toughness data are needed for assessing tritium reservoir structural integrity. This report provides data from J-Integral fracture toughness tests on unexposed and tritium-exposed weldments. The effect of tritium on weldment toughness has not been measured until now. The data include tests on tritium-exposed weldments after aging for up to three years to measure the effect of increasing decay helium concentration on toughness. The results indicate that Type 304L stainless steel weldments have high fracture toughness and are resistant to tritium aging effects on toughness. For unexposed alloys, weldment fracture toughness was higher than base metal toughness. Tritium-exposed-and-aged base metals and weldments had lower toughness values than unexposed ones but still retained good toughness properties. In both base metals and weldments there was an initial reduction in fracture toughness after tritium exposure but little change in fracture toughness values with increasing helium content in the range tested. Fracture modes occurred by the dimpled rupture process in unexposed and tritium-exposed steels and welds. This corroborates further the resistance of Type 304L steel to tritium embrittlement. This report fulfills the requirements for the FY06 Level 3 milestone, TSR15.3 "Issue summary report for tritium reservoir material aging studies” for the Enhanced Surveillance Campaign (ESC). The milestone was in support of ESC L2-1866 Milestone-“Complete an annual Enhanced Surveillance stockpile aging assessment report to support the annual assessment process”.

\section{Background}

Tritium and its decay product, helium, change the structural properties of stainless steels. Tritium exposed steels generally exhibit higher yield strength, lower elongation and ductility, lower fracture toughness and increased susceptibility to crack growth under sustained loads (1-10). The degree of property change depends on the tritium exposure history because it results from the dissolution and diffusion of tritium into the steel and its radioactive decay to helium.

At the Savannah River Site, welded stainless steel vessels are used for the containment of tritium gas. Weldments have not been well-characterized with respect to tritium embrittlement. Until now, almost all of the property data on the effects of tritium have been collected from studies done with base metals. Weldment microstructures are quite different than base metal microstructures chiefly because they contain the delta ferrite phase which forms during resolidification. Formation of delta ferrite is needed to prevent hot cracking during welding but it could be detrimental with respect to hydrogen and tritium compatibility. The purpose of this work was to measure the fracture toughness properties of weldments and compare them to base metal toughness. Furthermore, aged tritium-exposed alloys were tested to assess the combined embrittlement from tritium and its radioactive decay product, helium-3 on weldment toughness. 


\section{Experimental Procedure}

The composition of the steels and weld filler materials used in the study are listed in Table I. Type 304L Stainless Steel was used as the base metal and Type 308L was used as the weld filler wire. The base metal was supplied in the form of forward extruded cylindrical forgings.

In order to make the welds, notched groves were cut along the length of the Type 304L forging and the grooves were filled using the Gas Tungsten Arc (GTA) process and the Type 308L filler wire. Figure 1 shows the Type 304L forging and the welds. Additional welds were made using the same forging and Type 309L Modified (MOD) and Type 312 MOD filler wires. These filler wires produced GTA welds with higher ferrite contents. The results of the fracture toughness properties as a function of weld ferrite content will be the subject of a future report. A ferrite scope was used to measure the ferrite content at the root of the notch for each sample. For the welds used in this investigation, the weld ferrite content was approximately $8 \%$ by volume.

After welding, the forgings were sectioned into round discs and radiographed to verify that there was no unusual porosity, cracks, or other macroscopic defects from the welding process. This was done to ensure the fracture toughness samples were machined from high-quality welds and that any differences in properties could be attributed to the differences in ferrite content or microstructure.

Arc-shaped fracture-mechanics specimens having the shape and dimensions shown in Figure 2 were fabricated from the perimeter of each disc and oriented with their notches along the centerline of a weld. The samples were fatigue-cracked so that the crack-length to sample-width ratio was between 0.4 and 0.6. The size of the samples was chosen to be as large as possible to maximize constraint but thin enough to diffuse tritium into the samples at temperatures that would not alter the microstructure.

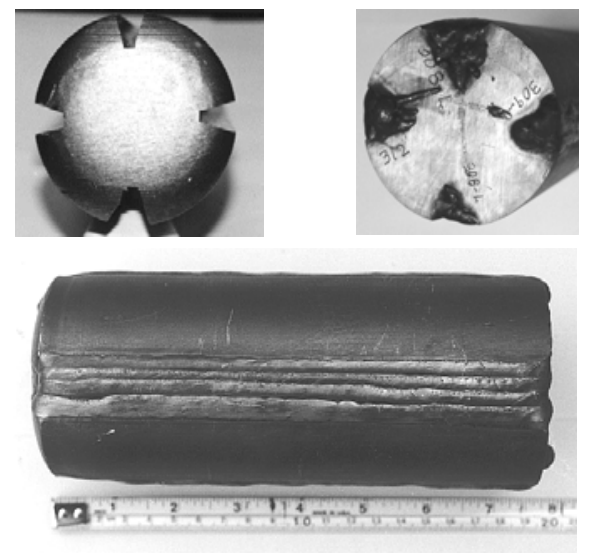

Figure 1. Type 304L Forging with Cut Grooves and Weldments Made Using Types 308L, 309L MOD, and 312 MOD Filler Materials.

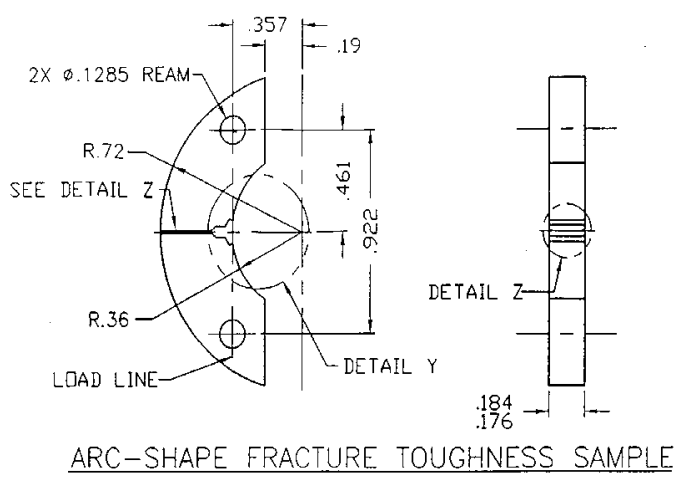

Figure 2. Shape and Dimensions of Fracture Toughness Sample. 
Table I. Compositions of Stainless Steel Forgings, Plates and Weld Filler Wires (Weight \%)

\begin{tabular}{|c|c|c|c|c|c|}
\hline Element & $\begin{array}{c}\text { 304L } \\
\text { Forging } \\
\text { (Base) }\end{array}$ & $\begin{array}{l}\text { 304L } \\
\text { Forging } \\
\text { (Welds) }\end{array}$ & $\begin{array}{l}308 \mathrm{~L} \\
\text { Filler }\end{array}$ & $\begin{array}{l}\text { 309L } \\
\text { MOD } \\
\text { Filler }\end{array}$ & $\begin{array}{c}312 \\
\text { MOD } \\
\text { Filler }\end{array}$ \\
\hline $\mathrm{Cr}$ & 18.0 & 19.9 & 20.5 & 23.5 & 28.7 \\
\hline $\mathbf{N i}$ & 11.3 & 10.4 & 10.3 & 8.55 & 9.17 \\
\hline Mn & 1.7 & 1.7 & 1.56 & 1.2 & 1.45 \\
\hline Mo & .039 & 0.04 & $<0.01$ & 2.5 & 0.27 \\
\hline $\mathrm{C}$ & .024 & 0.029 & 0.028 & 0.02 & 0.05 \\
\hline $\mathbf{S i}$ & .42 & 0.63 & 0.5 & 0.64 & 0.51 \\
\hline $\mathrm{Cu}$ & - & - & 0.015 & 0.31 & 0.31 \\
\hline $\mathbf{P}$ & .007 & 0.015 & 0.006 & 0.022 & 0.023 \\
\hline $\mathbf{S}$ & .003 & 0.002 & 0.012 & 0.008 & 0.008 \\
\hline $\mathbf{N}$ & .036 & 0.039 & 0.055 & & \\
\hline & & & & - & - \\
\hline Co & .027 & 0.03 & 0.068 & - & - \\
\hline $\mathbf{O}$ & - & - & - & - & - \\
\hline Al & -- & - & - & - & - \\
\hline
\end{tabular}

*304L composition from SRS ICPES analysis; all other heats are manufacturers' supplied

Table II. Tritium and Helium Contents for Tritium-Exposed Base Metal and Weldments

\begin{tabular}{|l|c|c|c|c|c|c|}
\hline $\begin{array}{c}\text { Material } \\
\text { Description }\end{array}$ & $\begin{array}{c}\text { Measured } \\
\text { Helium } \\
\text { Content* } \\
\text { (appm) }\end{array}$ & $\begin{array}{c}\text { Calculated } \\
\text { Initial } \\
\text { Tritium } \\
\text { Content } \\
\text { (appm) }\end{array}$ & $\begin{array}{c}\text { Aging } \\
\text { Time 1st } \\
\text { J-Integral } \\
\text { Test } \\
\text { (days) }\end{array}$ & $\begin{array}{c}\text { Calculated } \\
\text { Helium } \\
\text { Content for } \\
\mathbf{1}^{\text {st }} \text { Test } \\
\text { (appm) }\end{array}$ & $\begin{array}{c}\text { Aging } \\
\text { Time 2 } \\
\text { J-Integral } \\
\text { Test } \\
\text { (days) }\end{array}$ & $\begin{array}{c}\text { Calculated } \\
\text { Helium } \\
\text { Content for } \\
\mathbf{2}^{\text {nd }} \text { Test } \\
\text { (appm) }\end{array}$ \\
\hline $\begin{array}{l}\text { Type 304L } \\
\text { Base Metal }\end{array}$ & 129 & 1600 & 244 & 60 & 851 & 200 \\
\hline $\begin{array}{l}\text { Type } \\
\text { 304L/308L } \\
\text { Weldment }\end{array}$ & 216 & 1200 & 156 & 37 & 760 & 170 \\
\hline
\end{tabular}

*The helium content from tritium decay was measured on different dates for base metals and welds. The helium content in each sample on the day of the fracture toughness test was calculated from the measured helium and accounting for decay of tritium. 
Three sets of samples were prepared for this study. One set was tested in the as-forged or as-welded condition. The other two sets were exposed to tritium gas prior to testing. Tritium exposures were conducted at $623 \mathrm{~K}$ and an over-pressure of 5000 psi. One set of tritium-exposed samples was tested soon after charging ( $\sim 6$ months aged), and another tested approximately 24 months later ( 30 months aged). The temperature of exposure was designed to saturate the samples with tritium without changing the microstructure.

Tritium-charged samples were analyzed for helium concentration from tritium decay. The measured value of decay helium in the base metals agrees with the expected value calculated from tritium solubility, diffusivity, and decay. However, the measured value of decay helium in weldments was about 25 \% lower than those in the base metal for the same tritium exposure. Note in Table II, the base metals were estimated to have 1600 appm tritium while the welds had just 1200 appm tritium. The difference is attributed to the fact that tritium diffusivity values in ferrite are orders of magnitude higher than in austenite. Thus, weldments, which in this study contained about $8 \%$ ferrite, will have more tritium off-gassing during handling and storage. The lower initial value of tritium in the weldments means that helium will build-in at a reduced rate. This means that one cannot compare base metal properties to weld metal properties by using aging time. Instead the helium content at the time of each sample's test date was calculated from the measured values and by accounting for the decay of tritium from the test date to the date of the helium measurement. The results are shown in Table II.

J-integral tests were conducted at room temperature in air using a screw-driven testing machine and a crosshead speed of 0.002 in / min. while recording load, load-line displacement with a gage clipped to the crack mouth, and crack length. Crack length was monitored using an alternating DC potential drop system and guidelines described in ASTM E647-95. The J-Integral versus crack length increase ( $\mathrm{J}$ vs. da) curves were constructed from the data using ASTM E1820-99 (11). The $\mathrm{J}_{\mathrm{Q}}$ value is defined as the material fracture toughness and was obtained from the intercept of an offset from the crack tip blunting line with the J-da curve. For this study, the crack tip blunting line for the weldments was assumed to be the same as the blunting line for the base metal and was calculated from the yield strength and ultimate strength of the base metal per the ASTM 1820 procedure.

Because of the importance of the initial material microstructure on tritium aging behavior, the weld microstructures were characterized using standard metallographic techniques and transmission electron microscopy. Transmission electron microscopy (TEM) samples were prepared from the fractured toughness specimens. Three to four thin slices where sectioned from each specimen immediately adjacent to the fracture surface and within the weld zone (when present) providing samples with a range of microstructures and deformation levels. Two, $3 \mathrm{~mm}$ diameter disks were punched from each slice. Thin foils were prepared from these disks in a Fischione jet-polishing apparatus using a 57\% methanol, 39\% butylcellosolve, and 4\% perchloric acid solution at $35 \mathrm{~V}$ DC and $243 \mathrm{~K}$. All microscopy was performed using a JEOL 2010 operating at $200 \mathrm{kV}$. Fracture paths were characterized using scanning electron microscopy. 


\section{Results}

\section{Microstructural Characterization}

Figure 3 shows the typical forged microstructure for the Type 304L austenitic stainless steel used in this study. The microstructure consisted of grains that were slightly elongated in the direction of forging. The weld microstructure is shown in Figure 4. The welds consisted of a duplex structure of retained delta ferrite in austenite which is typical for Type 304L weldments. Note that Figure 4 indicates that the welds used in this study had a ferrite morphology consisting of discontinuous skeletal ferrite present in a predominant austenite matrix. A detailed microstructural analysis of all of the weldments is described in a separate report (12).

A significant microstructural feature in all the welds was a dispersion of fine inclusions produced during welding. These are important because their size and distribution can affect fracture toughness. The inclusions serve as potential microvoid nucleation sites during the dimpled rupture fracture process. The size and spacing of these inclusions can have a significant impact on fracture and fracture toughness.
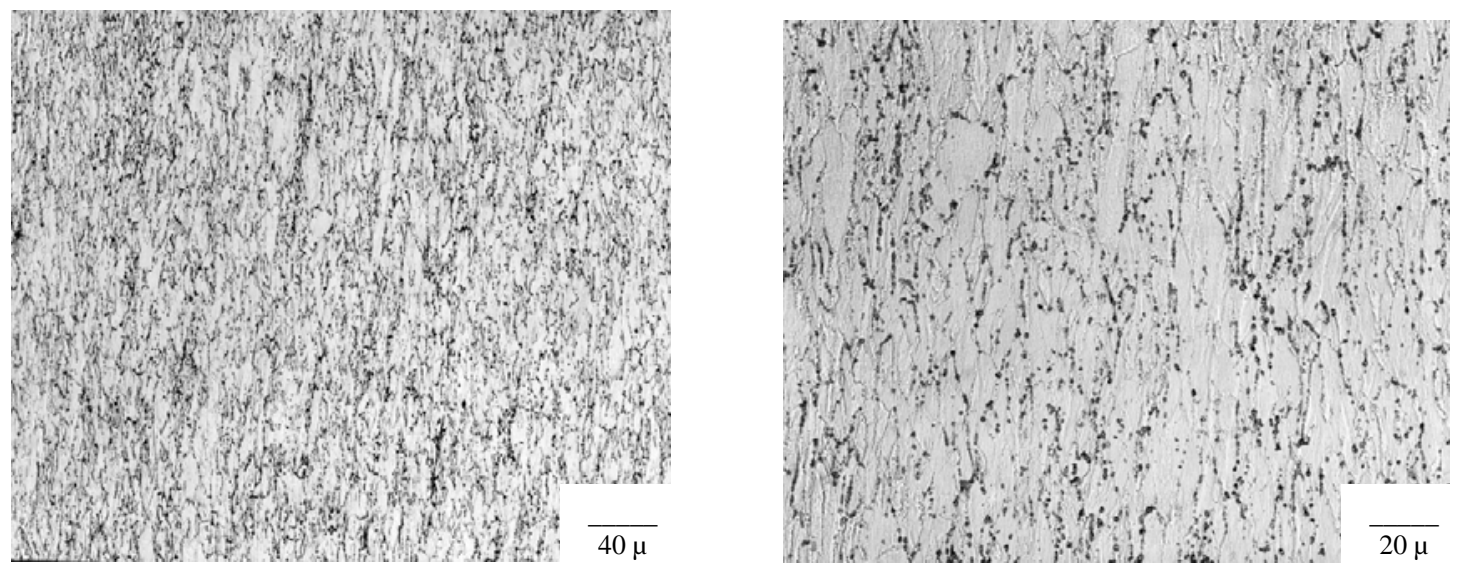

Figure 3. Typical Microstructure of Type 304L Base Metal Used in this Study.
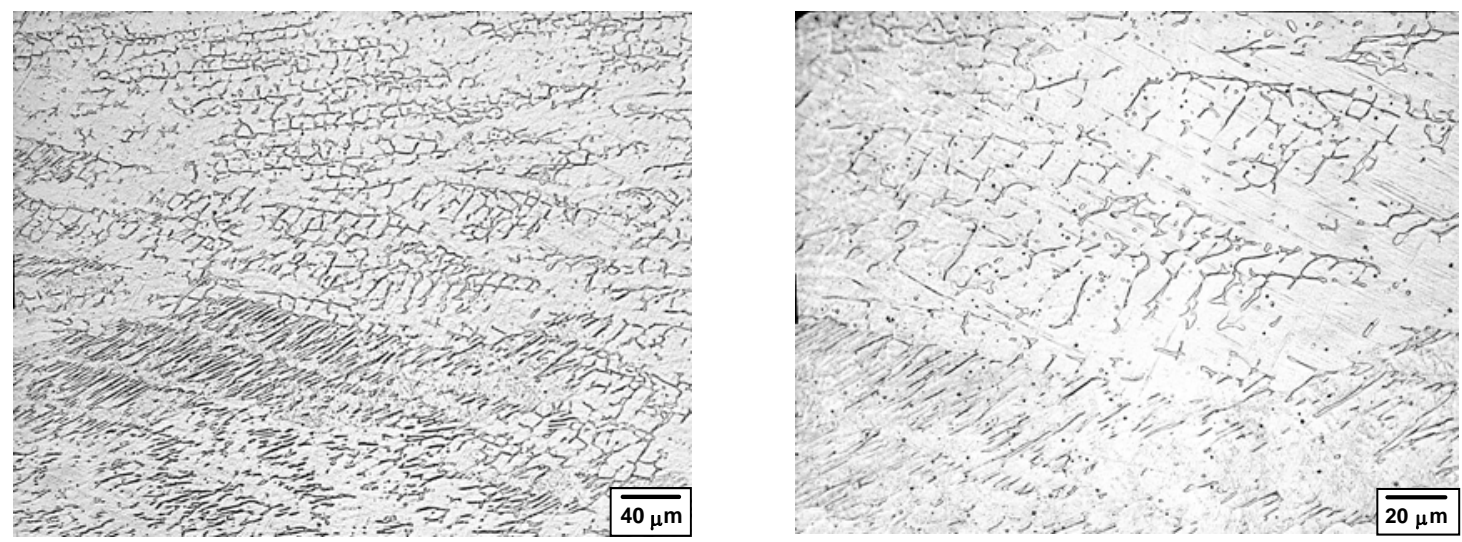

Figure 4. Microstructure of Welds that Consisted of Discontinuous Skeletal Ferrite in an Austenite Matrix. 
Transmission electron microscopy showed that the microstructure of the forged material consisted mainly of small, randomly orientated grains (Figure 5a). Figure 5(b) shows a selected area electron diffraction patterns that confirmed this observation. In general, these grains contained a high number density of dislocations. Infrequently, small, dislocation-free, recrystallized grains (or recrystallization nuclei) were observed.

Tritium-charged samples were also examined using TEM. Figure 6 shows typical helium bubble defects that are observed within the austenite phase of the welds. In general, helium bubbles (or their associated strain contrast) were readily visible in the recrystallized grains. These bubbles were small, measuring 1-2 $\mathrm{nm}$ in diameter and were randomly distributed throughout the grain interiors. In contrast, in regions with a high dislocation density very few bubbles were observed. It is generally believed that tritium is strongly attracted to dislocations.

Given the finite amount of tritium in the specimen material, the more dislocations there are in any one region, the less tritium and subsequently helium that is available to nucleate bubbles in the matrix. It is expected that incipient bubbles may have been present on the dislocations in the cold worked regions but were too small to be seen in the TEM images. TEM images provided limited evidence of bubbles on dislocations in the recrystallized regions but these images were unsuitable for publication. Finally, bubbles were not observed on any grain boundaries. Again, this is most likely due to the limited amount of tritium/helium in the sample available for visible bubbles to form on the extensive number of interfaces present in the material.

The helium bubble distribution illustrated in Figure 6 is from a weld containing the normal level of ferrite in these Type 304L/308L welds. Helium bubbles were observed only in the austenite matrix and not in the ferrite, on dislocations, or at austenite/ferrite or austenite/austenite boundaries. The failure to observe bubbles at these other locations does not necessarily preclude their presence, since bubbles measuring approximately $<0.8 \mathrm{~nm}$ are difficult to discern above the background image contrast. Additionally, the magnetic nature of ferrite in welded samples makes focusing TEM images at high magnifications difficult to perform.

Finally, Figure 7 shows the helium bubble microstructure observed in the forged material. In this particular micrograph, the interface between a recrystallized grain and a cold worked region was examined. Helium bubbles were visible in the recrystallized grain but not in the cold worked grain. This is most likely an artifact of the technique because the strain contrast needed for bubble observation is obscured by the strain contrast of the dislocations. 

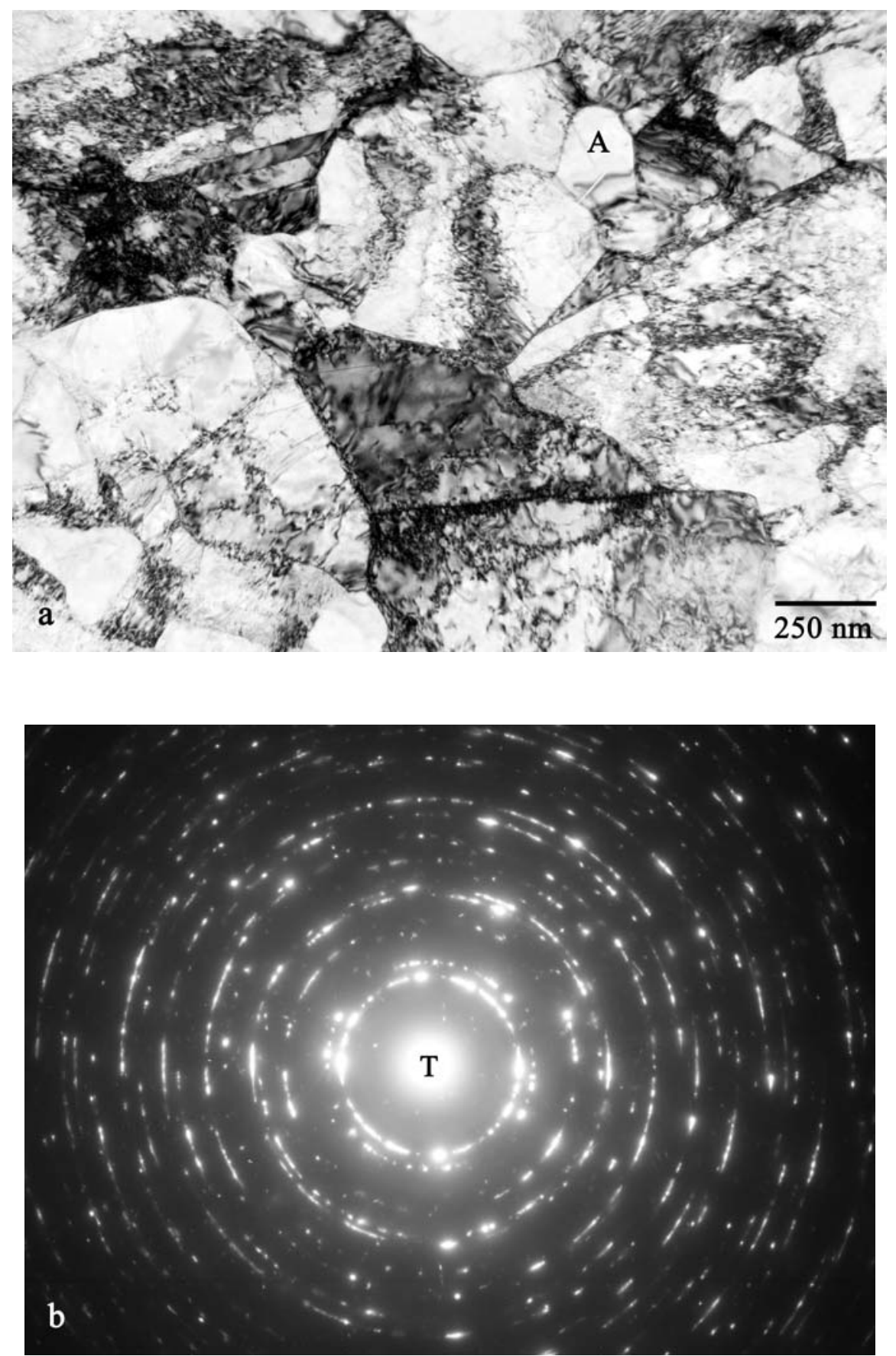

Figure 5. TEM images from the forged specimen material. The microstructure was comprised mostly of small, randomly oriented grains, shown in (a). A small, recrystallized grain is located at A. The image in (b) is the corresponding selected area electron diffraction pattern. 

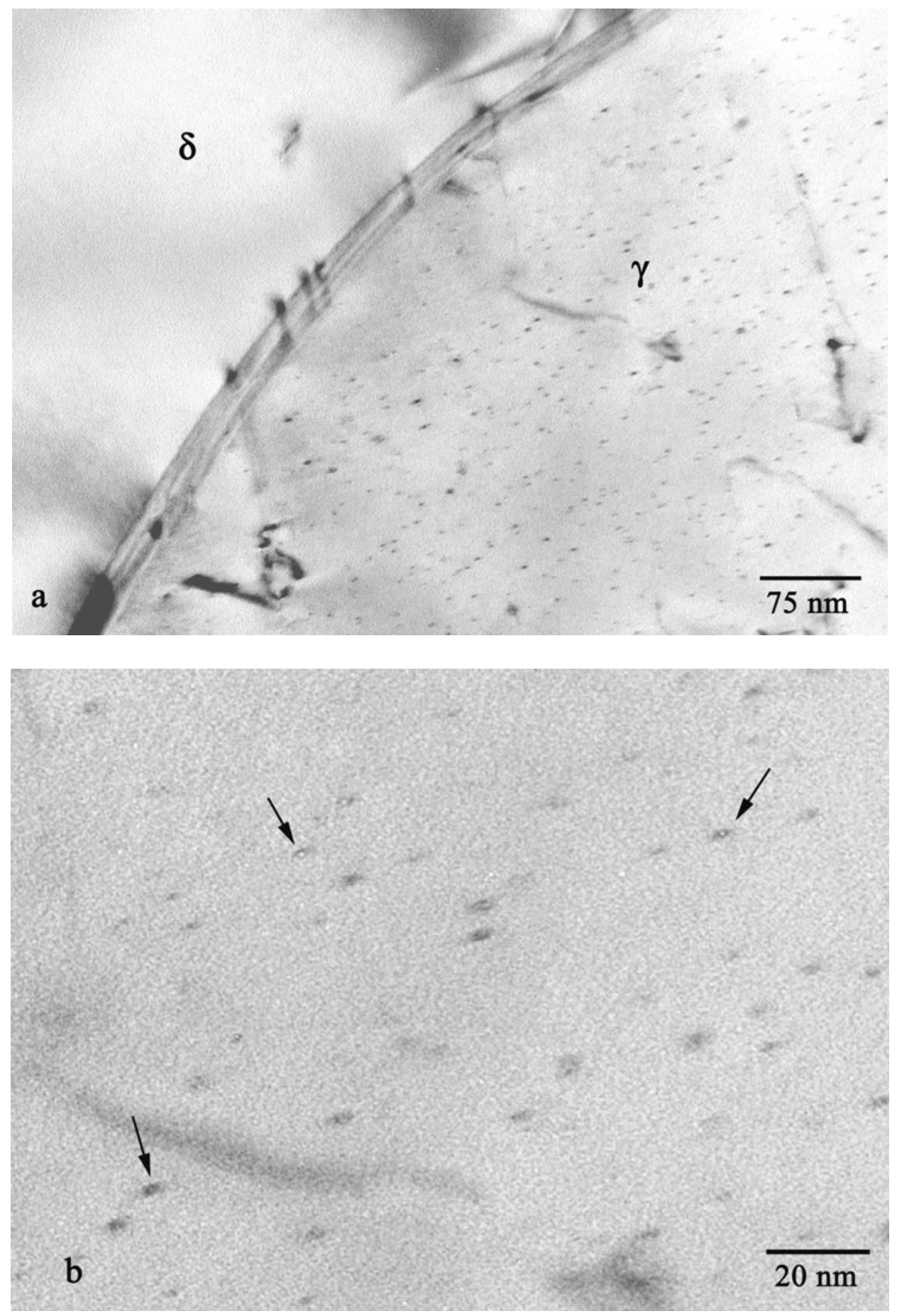

Figure 6. TEM images of (a) an Austenite/Ferrite Interface and (b) the Helium Bubble Distribution in the Austenite Grain in (a). The small, black "dots" in the austenite arise from strain contrast associated with helium bubbles. Several bubbles, measuring 1-2 nm in diameter, are arrowed in (b). 

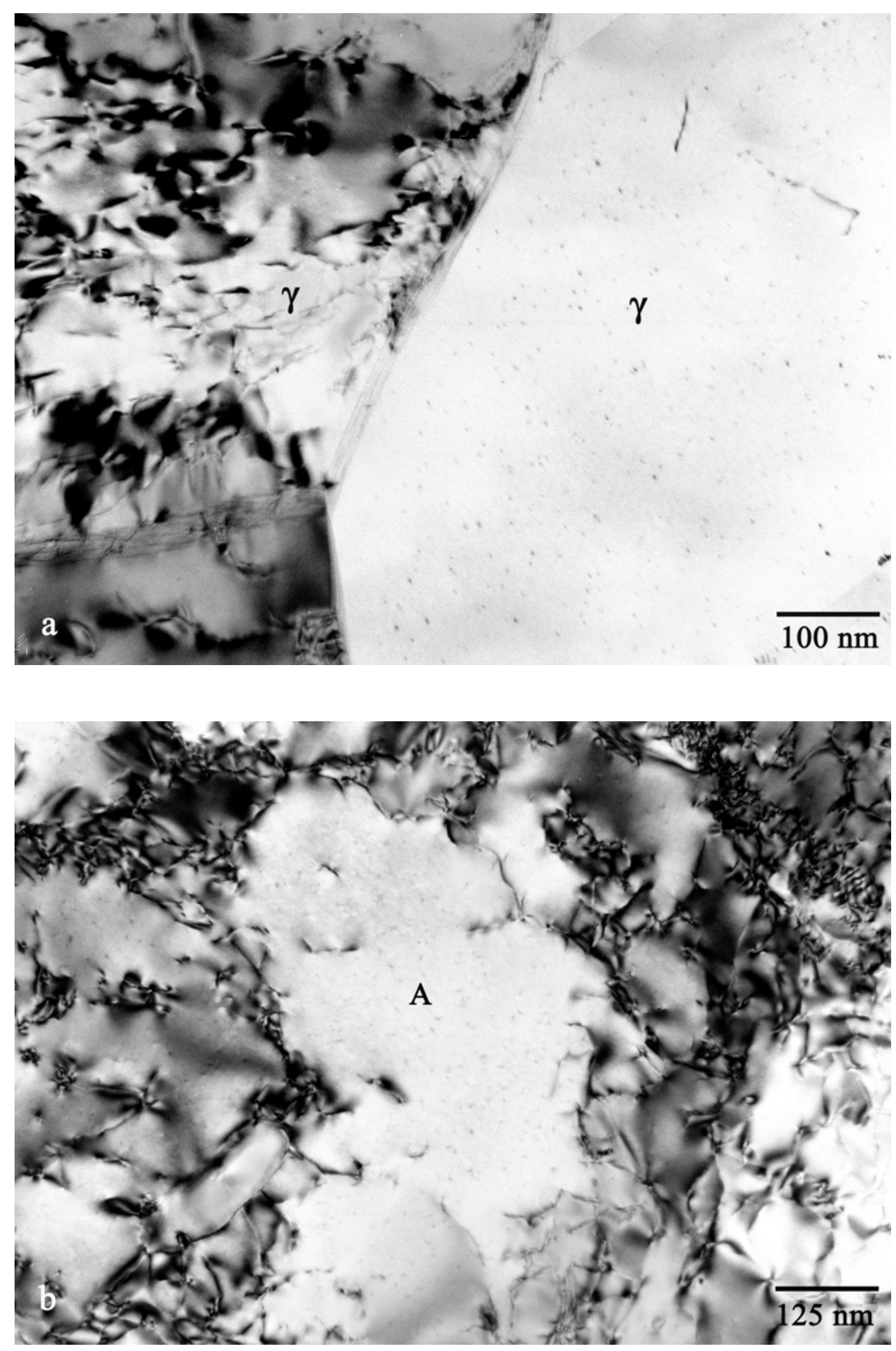

Figure 7. TEM Images from Forged Material. The image in (a) shows an interface between a recrystallized grain and a cold worked region. Bubbles are visible in the recrystallized grain as black dots but not the cold-worked region. In (b), a large number of bubbles are visible in a dislocation-free region (labeled A). 


\section{Fracture Toughness Tests}

A typical load-displacement record from a fracture toughness test and the corresponding potential drop signal is shown in Figure 8. A 3 amp DC current was applied across each sample and the increase in the voltage across the crack mouth was used to monitor the length of the crack during the fracture toughness. The area under the load-displacement diagram during the fracture toughness test represents the energy of fracture and is an indicator of the toughness of the alloy. From the area specific geometry factors for the C-specimen, and the crack length measurements, the actual fracture toughness value, $\mathrm{J}_{\mathrm{Q}}$ is calculated by using the standard ASTM procedures, in this case - ASTM E1820-99(11).

\section{CF 304L}

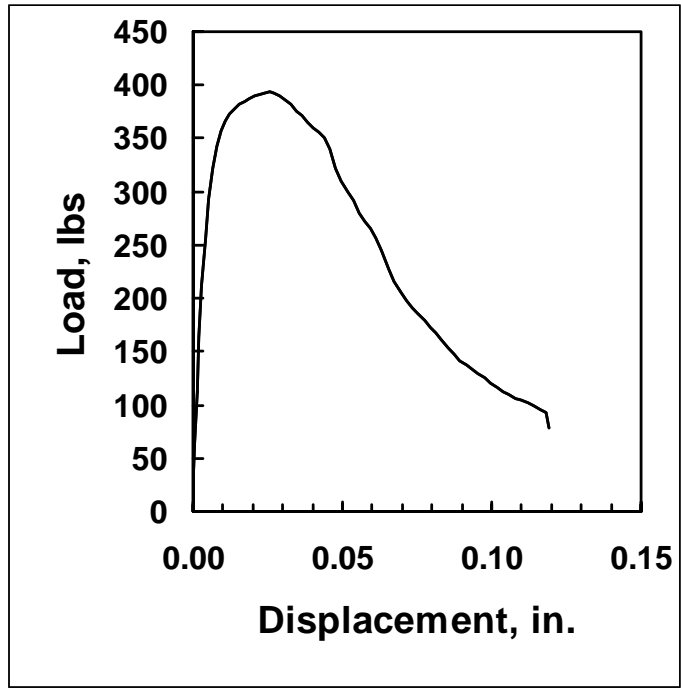

Load-Displacement

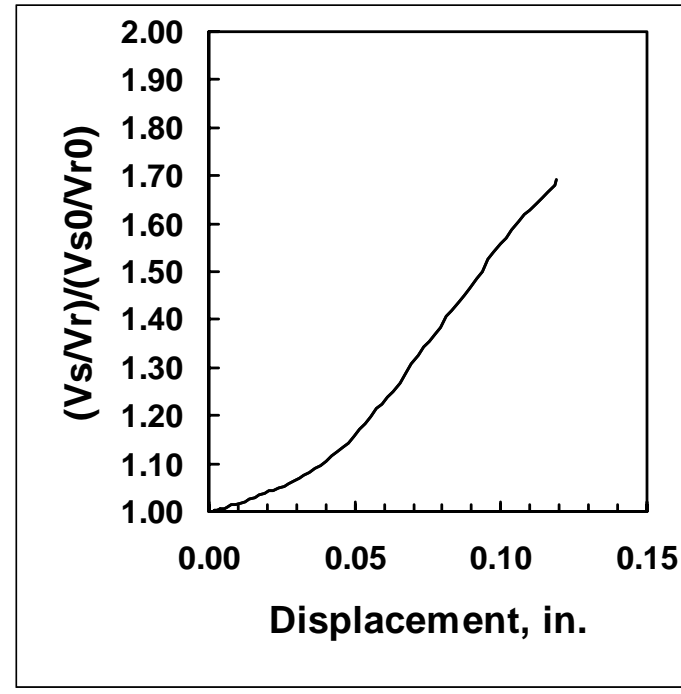

Normalized Voltage Across Crack

Figure 8. Typical Load-Displacement and Potential-Drop-Crack-Length-Measurement Records Acquired During Fracture Toughness Test.

The J-integral fracture toughness data are determined from plots of the J-Integral versus the change in crack length, da. The $J_{Q}$ fracture toughness data for all the samples are summarized in Table III. Typical J-da plots for the steels are shown in Figure 9 for the unexposed weldments and base metals. Note from Figure 9 that the unexposed weldments had fracture-toughness values two-to-three times higher than the base metal values. The presence of delta-ferrite in the microstructure, at least at these levels (8 volume \%) has a beneficial effect on fracture toughness and cracking resistance. The resistance to crack propagation was improved as well and is indicated by the steep slope for the J-da Type 308L weld data of Figure 9. 
Table III. Mechanical Properties and Fracture Toughness Values for Base Metals and Weldments

\begin{tabular}{|c|c|c|c|c|c|c|}
\hline $\begin{array}{c}\text { Material } \\
\text { Description }\end{array}$ & $\begin{array}{c}\text { Ferrite } \\
\%\end{array}$ & $\begin{array}{c}\text { Yield } \\
\text { Strength }\end{array}$ & $\begin{array}{c}\text { Ultimate } \\
\text { Strength }\end{array}$ & $\begin{array}{c}\text { 永 } \\
\text { As- } \\
\text { Received }\end{array}$ & $\begin{array}{c}\mathbf{J}_{\mathbf{Q}} \\
\text { Tritium- } \\
\text { Charged } \\
\text { \& Aged } \\
\mathbf{6} \text { Mos. }\end{array}$ & $\begin{array}{c}\mathbf{J}_{\mathbf{Q}} \\
\text { Tritium- } \\
\text { Charged } \\
\text { \& Aged } \\
\mathbf{3 0} \text { Mos. }\end{array}$ \\
\hline Type 304L & 0 & 67 & 105 & 1690 & 1024 & 1117 \\
\hline $\begin{array}{c}\text { Weldment } \\
\text { Type 304L/308L }\end{array}$ & 8 & 62 & 88 & 4975 & 1890 & 1494 \\
\hline
\end{tabular}

The effect of tritium exposure and aging on the base metal J-da behavior is shown in Figure 10. Tritium and its decay product, helium had the effect of lowering the resistance of the steel to crack initiation and growth as indicated by the lower $\mathrm{J}_{\mathrm{Q}}$ values and the less-steep J-da curves. Tritium and decay helium had a similar effect on the weld toughness. Note in Figure 11, that the weldment J-da curve was markedly lowered by tritium exposure and aging. The delta ferrite phase that had a beneficial effect on toughness for unexposed weldments had a detrimental effect on tritium-induced cracking resistance. The percent reduction by tritium and helium on toughness was greater for welds than base metals. Note that in Table III, the tritium-charged weldments had fracture toughness values reduced from $4975 \mathrm{lbs} /$ in to values range from 1500-1900 lbs / in while base metals had toughness reduced from about 1700 to $1100 \mathrm{lbs} / \mathrm{in}$.

Two sets of tritium-exposed samples were tested, one after approximately six months of aging and another after 24 months of aging. Neither base metals nor weldments showed much of a reduction in toughness with increased aging after the initial loss in toughness. This is shown in Figure 12 and the toughness values in Table III. This indicates that Type 304L stainless steel and its weldments are resistant to the embrittling effects of tritium and its radioactive decay product, at least at these helium levels.

One possible explanation for the reduced aging effects in weldments is that weld ferrite leads to tritium off-gassing losses during exposures and storage. Note that estimated concentrations of helium based on tritium solubility and decay for Type 304L stainless steel were in agreement with the measured values shown in Table II. However, the measured helium concentrations of the weldments were significantly lower than the base metals. Presumably the tritium levels in the aged weldments would be reduced more by off-gassing during aging than those in the base metals. Toughness would not decrease if enough tritium had been lost from off-gassing. 


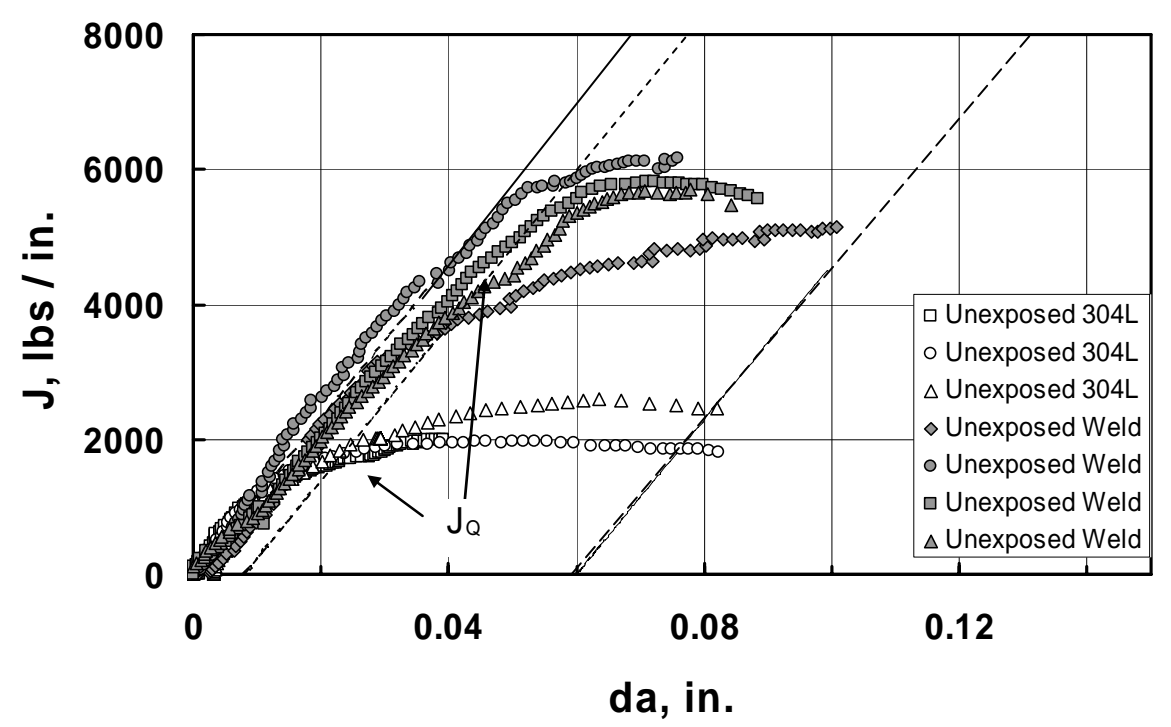

Figure 9. J-Integral vs. Change in Crack Length, J-da, Behavior for Unexposed Base Metals and Welds. Note that the weldments had higher fracture toughness values than base metals. $\mathrm{J}_{\mathrm{Q}}$ fracture toughness values were determined from the intercept of the offset line (See arrows).

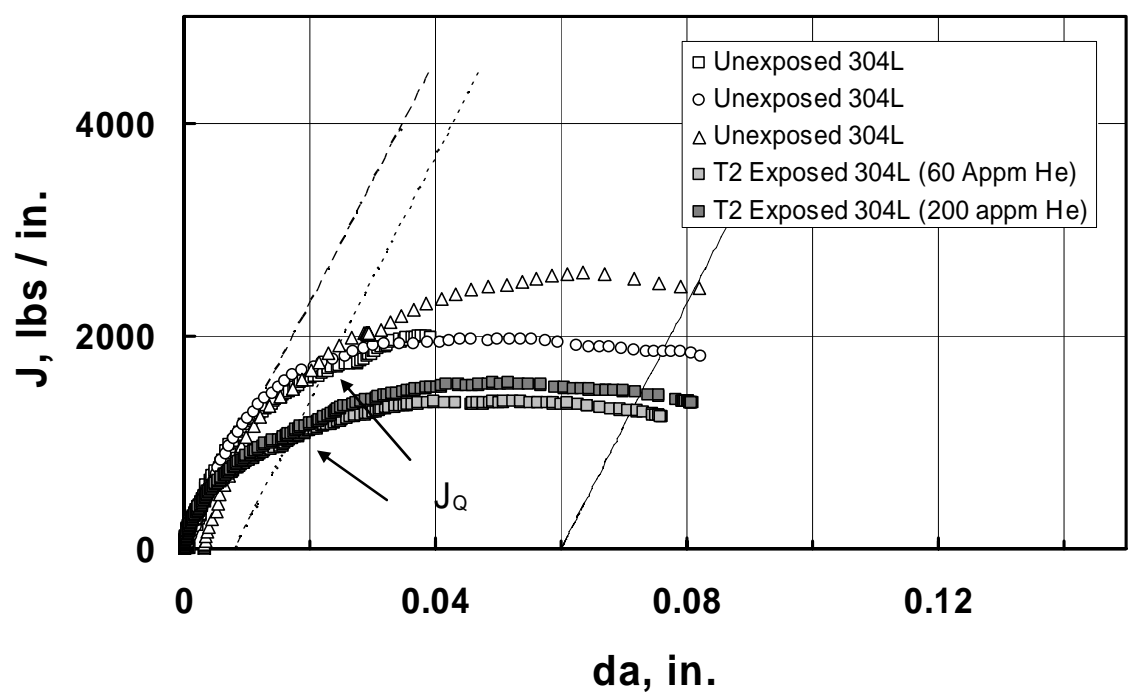

Figure 10. J-Integral vs. Change in Crack Length, J-da, Behavior for Unexposed and TritiumExposed Type 304L Base Metal. 


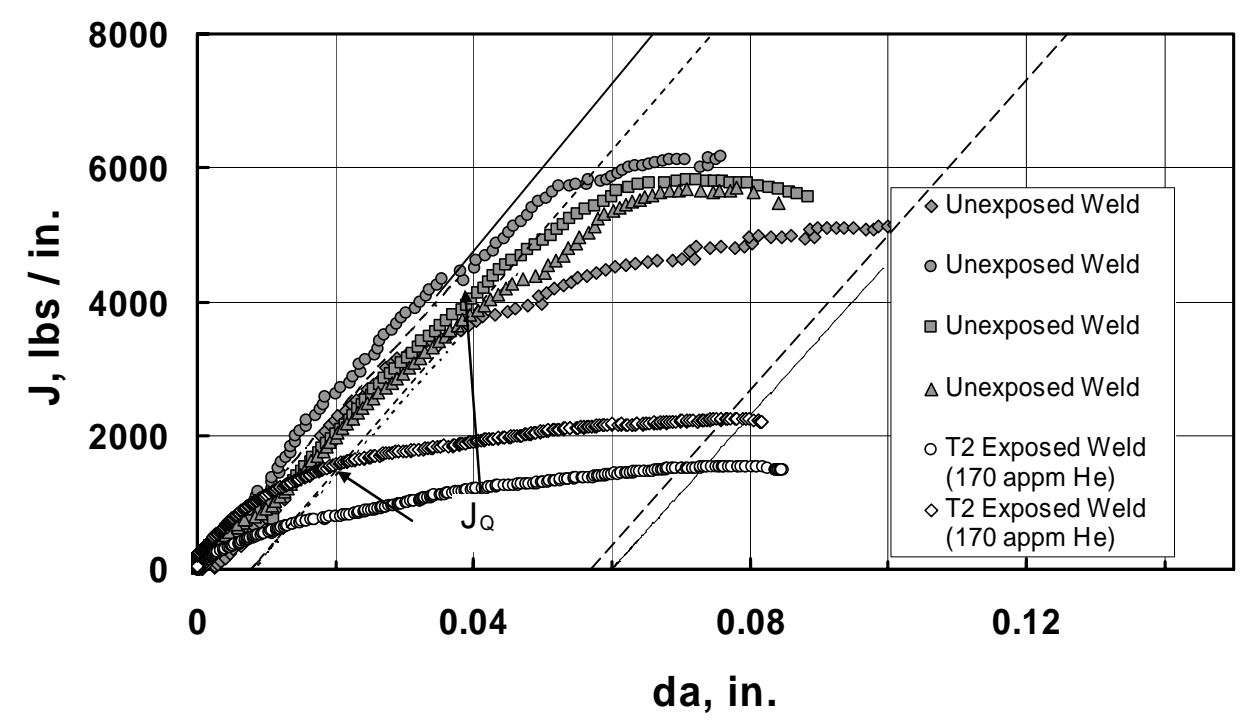

Figure 11. J-da Behavior for Unexposed and Tritium-Exposed Weldments. Only data for higher helium levels are shown.

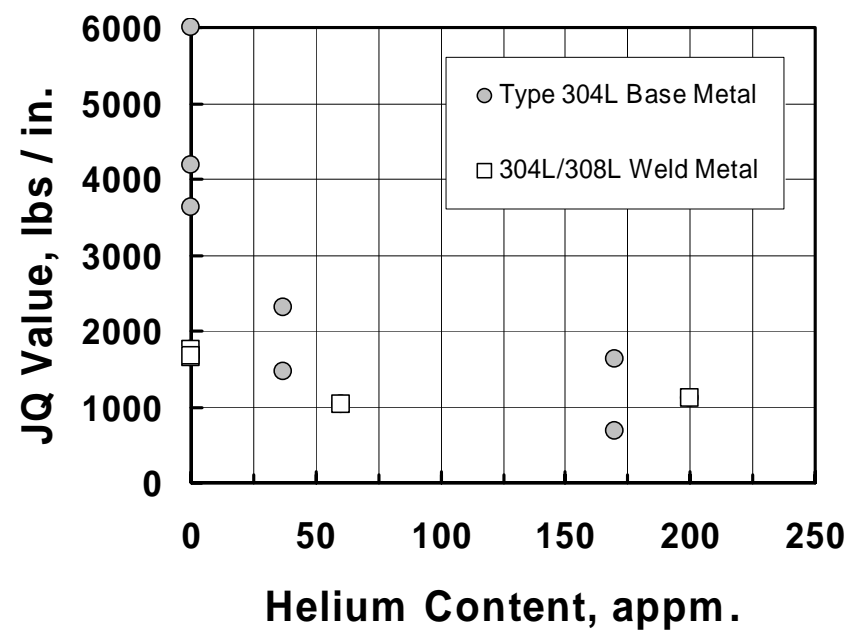

Figure 12. Reduction in Fracture Toughness with Increasing Helium Content. The fracture toughness values of Type 304L base metals and weldments are reduced to similar values for these helium contents. 


\section{Fractography:}

Fracture surfaces were examined using scanning electron microscopy. Examples of the fracture surfaces are shown in Figure 13 and Figure 14. In unexposed specimens, failure was dominated by the growth and coalescence of voids that had nucleated at inclusions (Figure 13a). Weldment fracture surfaces were characterized by finer voids than those on base metal fracture surfaces (Figure 13b).

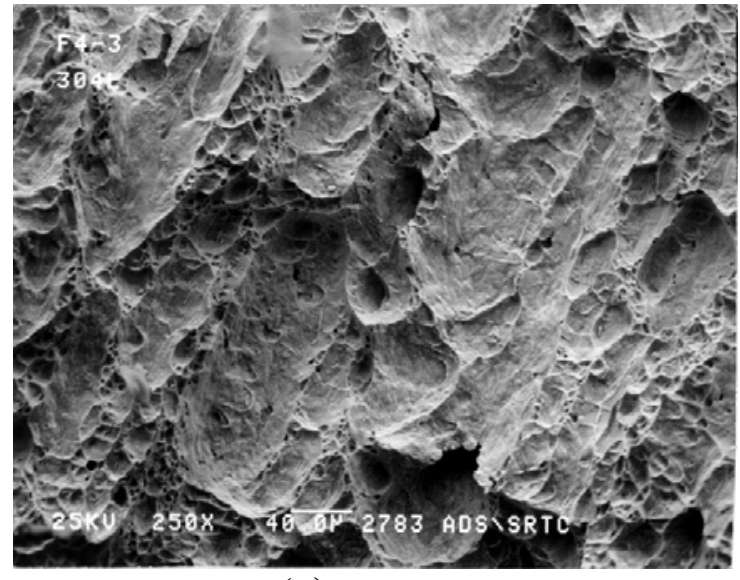

(a)

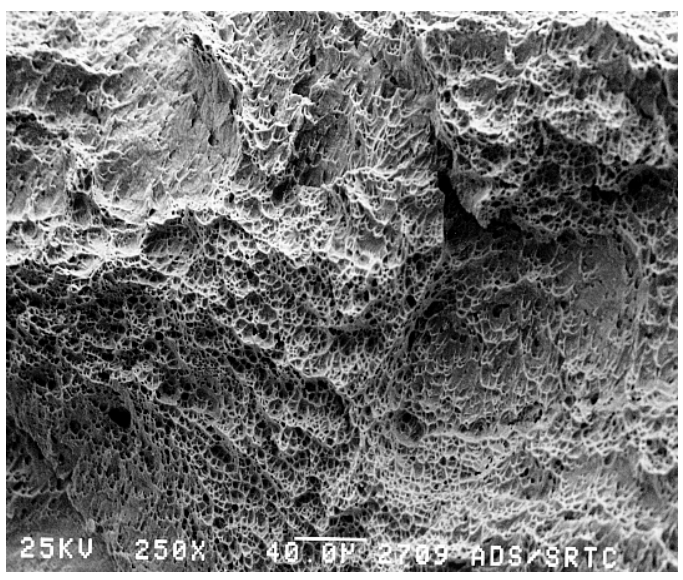

(b)

Figure 13. Fracture Appearance of Unexposed Steels: (a) Type 304L Base Metal and (b) Type 304L/308L Weld Metal. Crack propagation was from left to right.

Tritium exposed base metals had a dimpled rupture fracture mode that was somewhat different than the unexposed base metal. The fracture mode of the tritium-exposed base metals appeared to be banded (Figure 14a) when compared to the unexposed base metal (Figure 13a). This has been observed before in both hydrogen-and-tritium-exposed alloys and is caused by a hydrogen effect on the microvoid nucleation and growth process. Weldment fracture modes were essentially unaffected by tritium exposure (Figures 14b). This was surprising given the large fracture toughness reduction observed in the weldments of Figure 12. In a few areas, evidence for fracture through the ferrite phase or along the ferrite-austenite interfaces could be seen on the weldment fracture surfaces (See arrow, Figure 14b).

\section{Discussion}

The results of the fracture toughness tests show that Type 304L stainless steel weldments have higher fracture toughness values than the base metals. At these ferrite levels the toughness improvement that resulted from weld ferrite is in agreement with the stainless steel weldment behavior described in a recent review by Mills (13). Mills indicates that ferrite phases in austenitic stainless steel weldments are brittle at low temperature and stainless steel welds exhibit a ductile-brittle transition temperature phenomenon. However, at ambient and elevated temperatures, Mills shows that the ferrite phase behaves in a ductile manner, and welds are more resistant to fracture. The weldments in this study failed by a similar fracture process that Mills describes. 


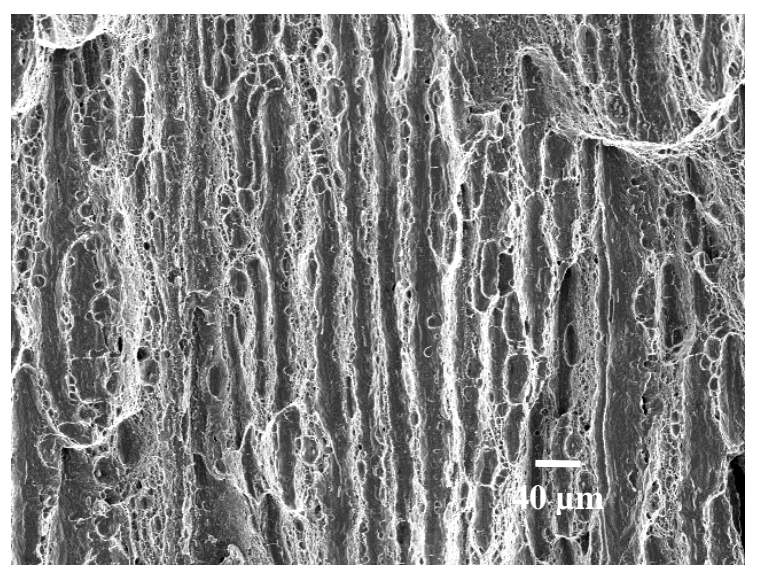

(a)

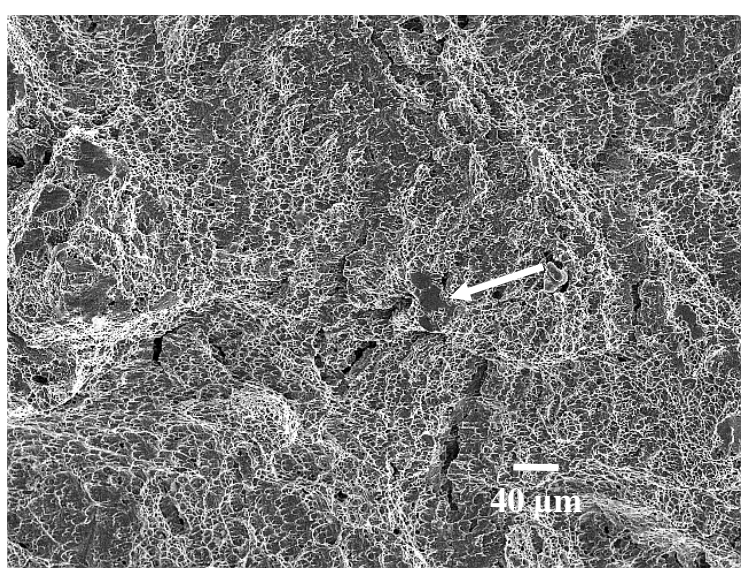

(b)

Figure 14. Fracture appearance of tritium-exposed samples: (a) Type 304L Base Metal; and (b) Type 304L/308L Weld Metal. Note there was some evidence of tritium induced fracture through ferrite or along the ferrite-austenite interface (arrow) of the weld metal.

With regard to the effects of tritium on the weldment toughness, the fracture modes of the tritiumexposed alloys are similar to observations on the effects of hydrogen made by other researchers (14, 15). Brooks suggests that hydrogen-induced fracture occurs along or near the austenite-ferrite boundary in welds and that the hydrogen-exposed welds can exhibit hydrogen induced fracture mode changes (14). Luppo also investigated the effects of delta ferrite on hydrogen embrittlement of austenitic stainless steel welds (15). A hydrogen-microprint technique was used to demonstrate that ferrite-austenite interfaces acted as traps for hydrogen. Although the fracture modes of the weldments showed very little change in overall appearance there were patches of fracture that looked to be along the delta ferrite interfaces (Figure 14b).

Tritium-exposed-and-aged weldments fracture in ways that are similar to those described by researchers who have investigated fracture of irradiated stainless steels. For example, O’Donnell demonstrated that an irradiation dose of 4 displacements per atom (dpa) of weld metal of Type 316 stainless steel severely lowered the J-R curve (16). In this study, tritium-exposed steels had lower J-R curves than unexposed steels (Figures 10 and 11). In this and O'Donnell's study, welds were more significantly affected than the wrought metal (Figure 12). A significant microstructural feature of the weld metal in both studies is the dispersion of fine inclusions produced during welding. The combination of higher particle volume fraction and continuous weld ferrite had their most severe effects on toughness when hydrogen or tritium is present.

Both the base metals and weldments showed high resistance to tritium embrittlement. Though both weldments and base metals had fracture toughness values lower after tritium exposure, neither showed a large reduction in toughness with the increased aging. This indicates that Type 304L stainless steel is highly resistant to the effects of tritium and decay helium. One question that may require further work is whether or not off-gassing of tritium from crack tips during handling and testing could have significant impact on the fracture behavior. The weldments had much higher off- 
gassing losses of tritium during handling and storage as indicated by the helium levels. Note that Table II shows that measured helium concentrations of weldments are lower than base metal concentrations for these tritium exposures. Toughness would not decrease as much with aging time if much of the tritium had already been reduced significantly from off-gassing.

In summary, tritium and decay helium have negative effects on the fracture toughness properties of stainless steel weldments. The fracture toughness properties of stainless steels and its weldments are needed if progress can be made on building predictive models for the tritium-induced cracking program. The Lifecycle Engineering (LCE) Program for Tritium Reservoirs is one such program. The data from this study will be used in that modeling effort to help further understand tritium aging in tritium reservoir containment alloys.

\section{Conclusions}

1. For unexposed Type 304L stainless steel, the fracture toughness of weldments was two to three times higher than the base metal toughness. Microstructural analysis indicated that the discontinuous skeletal ferrite present in the austenite matrix of the weldments provides a beneficial effect on fracture toughness provided no hydrogen or tritium is present in the microstructure.

2. Tritium exposure lowered the fracture toughness properties of both base metals and weldments. This was characterized by lower $\mathrm{J}_{\mathrm{Q}}$ values and lower J-da curves. The percent reduction was greater for weldments apparently because the delta ferrite interfaces are weakened by hydrogen isotopes and helium making it easier for microvoids to nucleate and coalesce.

3. Tritium-exposed-and-aged base metals and weldments had lower fracture toughness values than unexposed ones but still retained good toughness properties.

4. Fracture modes were dominated by the dimpled rupture process in unexposed and tritiumexposed steels and welds. Weld fracture surfaces showed some evidence for tritium-induced cracking of ferrite or ferrite-austenite interfaces.

\section{Future Work}

The results of this study suggest directions for future work. Measurements on the tritium aging behavior and fracture toughness properties of other tritium containment alloys like Type 21-6-9 and Type 316L stainless steels need to be conducted. The characterization of helium effects on toughness of base metals and weldments should be conducted on samples containing higher levels of decay helium because the containment alloys could have helium contents greater than those in this study. This can be done using the samples from this study but will require aging and testing out through FY08. Slow crack growth threshold measurements on tritium-exposed weldments should be conducted and the results compared to the rising load J-Integral fracture toughness properties in this study. Finally the design, procurement, construction and installation of facilities needed for testing tritium-exposed-and-aged samples in hydrogen environments are needed particularly for refined 
weldment investigations. Off-gassing of tritium from crack tips during handling and testing could have significant impact on the fracture behavior of these alloys.

\section{Acknowledgement}

The authors wish to thank Glenn Chapman for his dedication and assistance in this project, particularly in making the welds and conducting the fracture toughness tests.

\section{References}

1. A. J. West and D. E. Rawl, Jr., Proc. Conf. on Tritium Technology in Fission, Fusion and Isotopic Applications, (Dayton, OH: American Nuclear Society, 1980), p. 69.

2. J. West, Jr. and M. R. Louthan, Jr., "Hydrogen Effects on the Tensile Properties of 21-6-9 Stainless Steel", Metallurgical Transactions A, 13A (1982), p. 2049.

3. G. R. Caskey, Jr., "Hydrogen Effects in Stainless Steels", Hydrogen Degradation of Ferrous Alloys, ed. J. P. Hirth, R. W. Oriani, and M. Smialowski, eds., (Park Ridge, NJ: Noyes Publication, 1985), p. 822.

4. D. G. Ulmer and C. J. Altstetter, "Mechanism For Hydrogen Embrittlement of Austenitic Stainless Steels", Proc. Fourth Int. Conf. on Hydrogen Effects on Material Behavior, ed. A. W. Thompson and N. R. Moody, (Warrendale, PA: The Minerals, Metals \& Materials Society, 1989), p. 421.

5. G. R. Caskey, Jr., "Tritium-Helium Effects in Metals", Fusion Technology, 8, 1985, 2293-2298.

6. M. J. Morgan and M. H. Tosten, "Tritium and Decay Helium Effects on the Fracture Toughness Properties of Types 316L, 304L, and 21Cr-6Ni-9Mn Stainless Steels”, Hydrogen Effects in Materials, ed. A. W. Thompson and N. R. Moody, (Warrendale, PA: TMS, 1996), p. 873.

7. B. C. Odegard, J. A. Brooks, and A. J. West, "The Effect of Hydrogen on the Mechanical Behavior of Nitrogen Strengthened Stainless Steel", Effect of Hydrogen on the Behavior of Materials, ed. A. W. Thompson and I. M. Bernstein, (Warrendale, PA: The Metallurgical Society of AIME, 1976), p. 116.

8. M. J. Morgan and M. H. Tosten, "Microstructure and Yield Strength Effects on Hydrogen and Tritium Induced Cracking in HERF Stainless Steel", Hydrogen Effects on Material Behavior, ed. N. R. Moody and A. W. Thompson, (Warrendale, PA: TMS, 1990), 447-457.

9. M. J. Morgan "The Effects of Hydrogen Isotopes and Helium on the Flow and Fracture Properties of 21-6-9 Stainless Steel”, Proc. Fine Symposium, ed. P. K. Liaw, J.R. Weertman, H. L. Marcus, and J. S. Santner, (Warrendale, PA: TMS, 1990), 105-111. 
10. S. L. Robinson, "The Effects of Tritium on The Flow and Fracture of Austenitic Stainless Steels", Proc. Fourth Int. Conf. on Hydrogen Effects on Material Behavior, ed. A. W. Thompson and N. R. Moody, (Warrendale, PA: The Minerals, Metals \& Materials Society, 1989), p. 433.

11. ASTM E 1820-99 “Standard Test Method for Measurement of Fracture Toughness", 1999 Annual Book of ASTM Standard Volume 3.01 Metals-Mechanical Testing; Elevated and LowTemperature Tests; Metallography, American Society for Testing and Materials, 1999.

12. M. H. Tosten and M. J. Morgan, "Transmission Electron Microscopy Study of Helium-Bearing Fusion Welds”, WSRC-TR-2005-00477, November, 2005.

13. W. J. Mills, "Fracture Toughness of Type 304 and 316 Stainless Steels and Their Welds", International Materials Reviews, 42 (2) (1997), 45-82.

14. J. A. Brooks and A. J. West, "Hydrogen Induced Ductility Losses in Austenitic Stainless Steel Welds”, Metallurgical Transactions A, 12A, (1981) 213-223.

15. M. I. Luppo, A. Hazarabedian, and J. Ovejero-Garcia, "Effects of Delta Ferrite on Hydrogen Embrittlement of Austenitic Stainless Steel Welds”, Corrosion Science, 41 (1999) 87-103.

16. J. O'Donnell, H. Huthmann, and A. A. Tavassoli, "The Fracture Toughness Behavior of Austenitic Steels and Weld Metal Including the Effects of Thermal Aging and Irradiation”, Int. J. Pres. Ves. \& Piping, 65 (1996), 209-220. 